Western North American Naturalist 69(3), (C) 2009, pp. 343-350

\title{
EFFECTS OF SIMULATED MOUNTAIN LION CACHING ON DECOMPOSITION OF UNGULATE CARCASSES
}

\author{
Zachary Bischoff-Mattson ${ }^{1,3}$ and David Mattson ${ }^{2}$
}

\begin{abstract}
Caching of animal remains is common among carnivorous species of all sizes, yet the effects of caching on larger prey are unstudied. We conducted a summer field experiment designed to test the effects of simulated mountain lion (Puma concolor) caching on mass loss, relative temperature, and odor dissemination of 9 prey-like carcasses. We deployed all but one of the carcasses in pairs, with one of each pair exposed and the other shaded and shallowly buried (cached). Caching substantially reduced wastage during dry and hot (drought) but not wet and cool (monsoon) periods, and it also reduced temperature and discernable odor to some degree during both seasons. These results are consistent with the hypotheses that caching serves to both reduce competition from arthropods and microbes and reduce odds of detection by larger vertebrates such as bears (Ursus spp.), wolves (Canis lupus), or other lions.
\end{abstract}

Key words: Puma concolor, caching, decomposition, carcass, odor, Arizona, mountain lion.

Mountain lions (Puma concolor) often relocate prey killed in the open to shaded microsites, where they may then cover the carcass with a shallow layer of soil and organic debris (Hansen 1992). Cached kills are typically exhumed, consumed, and inhumed (often in new microsites) in cycles, until most fleshy material is gone and the lion leaves. For most large (>30 kg) prey, this process lasts 2-4 days (Anderson and Lindzey 2003, Mattson et al. 2006). Prey caching of various forms is widespread among carnivorous species, including species from Soricidae, Mustelidae, Felidae, Canidae, Hyaenidae, and Ursidae (e.g., Kruuk 1972, Macdonald 1976, Eltringham 1979, Elgmork 1982, Muths 1998, Mech and Adams 1999, Michener 2000, Červený and Okarma 2002, Samelius et al. 2002). Despite the commonness of this behavior, very few studies have specifically investigated the sequestration of animal remains, in contrast to widespread attention given by researchers to caching and hoarding of vegetal material by birds, rodents, and squirrels (Smith and Reichman 1984, Vander Wall 1990). Mountain lions in northern Arizona relocate or bury kills more often at hotter temperatures, at lower elevations, on southerly exposures, and in areas with greater forest and herbaceous cover (Mattson et al.
2006). They also cache carcasses of intermediate mass (47-131 kg) more often. These results suggest that lions in this region cache prey more often when it is energetically economical, when ambient conditions substantially elevate temperatures of exposed carcasses, and when shade is available.

Researchers have speculated about the reasons carnivores, generally, and mountain lions, in particular, cache prey. For smaller species the size of shrews (Blarina and Cryptotis) and foxes (Alopex and Vulpes), scatter-hoarding plausibly serves to attenuate the temporal availability of seasonally abundant prey (Martin 1984, Fornamowicz et al. 1989, Sklepkovych and Motevecchi 1996, Samelius et al. 2007). For larger species, caching has been speculated to reduce competition with microbes, arthropods, and vertebrate scavengers. Grizzly bears (Ursus arctos), wolves (Canis lupus), and larger conspecifics can drive mountain lions from kills (Murphy et al. 1998, Kunkel et al. 1999), and Hornocker (1970), Beier et al. (1995), and Ruth (2004) hypothesized that caching inhibits dissemination of odors, thereby reducing odds of kleptoparasitism. Caching could also inhibit detection by smaller vertebrates such as coyotes (Canis latrans) and ravens (Corvus corax), which, while not likely to

\footnotetext{
${ }^{1}$ Lewis and Clark College, Department of Biology, 0615 Palatine Hill Rd. MSC 53, Portland, OR 97219.

${ }^{2}$ Corresponding author. U.S. Geological Survey, Southwest Biological Science Center, Colorado Plateau Research Station, Box 5614, Flagstaff, AZ 86011. E-mail: david.mattson@nau.edu

${ }^{3}$ Present address: Grand Canyon Trust, 2601 N. Fort Valley Road, Flagstaff, AZ 86001
} 
displace an adult lion, have nonetheless been shown capable of consuming large volumes of unprotected carrion (DeVault et al. 2003). However, these speculations have not been tested.

Hornocker (1970) and Beier et al. (1995) also hypothesized that caching retards decomposition by keeping carcasses cool and reducing arthropod access to tissues. Forensics and entomological studies have shown that carcass wastage and abundance of necrophilous arthropods are retarded by cooler ambient and carcass temperatures associated with site, season, or shading (Braack 1986, Isiche et al. 1992, Tessmer and Meek 1996, Kočárek 2003, Watson and Carlton 2005, Joy et al. 2006). Burial or other covering has been shown to slow decomposition (Mann et al. 1990, Goff 1992, Turner and Wiltshire 1999). Retarded wastage has also been associated with comparatively higher precipitation and lower broadscale densities of arthropods, which are conditions typical of high elevations (Payne 1965, Tantawi et al. 1996, DeJong and Chadwick 1999, Martinez et al. 2007). However, no study has investigated the effects of mountain lion caching behavior (shading and shallow burial) on decomposition rates and odor dissemination of ungulate carcasses.

In this paper, we report the results of a field experiment designed to elucidate the effects of shading and shallow burial on carcasses of a size and shape typical of mountain lion prey, at a site representative of mountain lion habitat in northern Arizona. Climatic region and carcass morphology have potentially substantial effects on carcass wastage rates (Catts and Goff 1992, Watson and Carlton 2003), which have led forensics researchers to study cadaver decomposition under a wide range of conditions. We were interested in the effects of sequestration, carcass size, and weather on carcass temperature, odor dissemination, and wastage from arthropods and microbes. Our primary research hypotheses were the following: (1) wastage rates $\left(\mathrm{kg} \cdot \mathrm{h}^{-1}\right)$ are lower for cooler versus hotter carcasses, (2) wastage rates are lower for cached (treated) versus exposed (untreated) carcasses, (3) carcass surface temperatures are lower relative to ambient temperatures for treated versus untreated carcasses, and (4) odor detection occurs at lesser distances from treated versus untreated carcasses.

\section{Methods}

Our study area was located at $35.483^{\circ} \mathrm{N}$, $111.614^{\circ} \mathrm{W}$, north of the San Francisco Peaks, in Coconino County, Arizona, on the Coconino National Forest. The site is at 2024-2047 m elevation on volcanic cinder soils in mixed piñon pine (Pinus edulis) and juniper (Juniperus osteosperma) woodland with a patchy blue grama (Bouteloua gracilis) ground layer. We located our study site well away from point water sources and from areas known to be inhabited by black bears (Ursus americanus) to minimize odds of bears scavenging deployed carcasses. We delineated areas with little bear activity based on our 5 years of fieldwork in the area and on consultation with biologists from the Arizona Game and Fish Department (AGFD).

The study-area climate is temperate semiarid. Nearby Flagstaff, Arizona, has a July mean temperature of $19.1^{\circ} \mathrm{C}$ and, on average, experiences 3 days a year with maximum temperatures $>32{ }^{\circ} \mathrm{C}$. Summertime precipitation is concentrated from mid-July through midSeptember and is spatially highly patchy in association with localized thunderstorms. A strong spring and early-summer drought typically lasts from mid-April through the first week in July. For purposes of analysis, we recorded precipitation at our study sites with 2 rain gauges, each located within $0.5 \mathrm{~km}$ of deployed carcasses, and we used daily maximum and minimum temperatures recorded at Wupatki National Monument, which is roughly $8 \mathrm{~km}$ from our study site and $540 \mathrm{~m}$ lower in elevation.

With one exception (see results), our design consisted of deploying pairs of carcasses of the same species during roughly the same time period within our homogeneous study site. One carcass of each pair was placed uncovered in the open, and the other was placed in the shade of a mature juniper, buried under a thin (ca. 5-cm) layer of soil and organic debris. Deployments occurred within a 3-month period. In order to ensure independence, we dispersed carcasses widely enough $(0.25-0.35$ $\mathrm{km}$ intervals) to minimize odds that odors would be mistakenly attributed to the wrong carcass or that local increases in arthropod populations attributable to one carcass would affect another. We obtained carcasses from AGFD and also by routinely patrolling area 

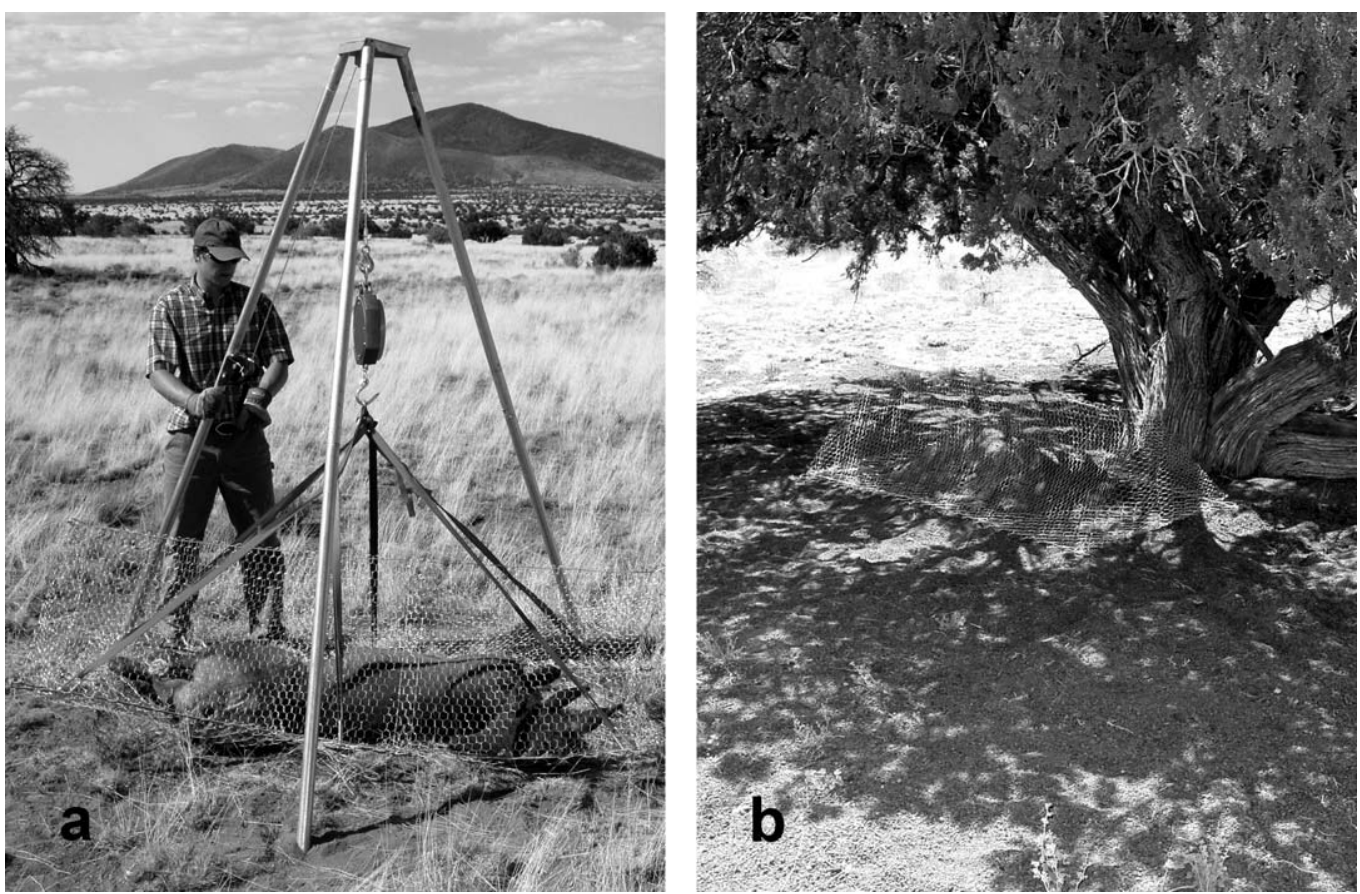

Fig. 1. (a) An example of the wire-mesh exclosure used during this study, elevated to measure the mass of an elk carcass deployed exposed (untreated) during summer 2007 north of Flagstaff, Arizona, and (b) an example of a carcass deployed buried (treated) in the shade of a juniper.

highways for roadkills and by responding to Arizona Department of Transportation reports of roadkills. We only used carcasses that were prebloat and in relatively intact condition.

We deployed carcasses in wire-mesh exclosures to minimize losses of tissue to birds and mesocarnivores, such as gray foxes (Urocyon cinereoargenteus) and coyotes. Exclosures were constructed out of 4.8-cm 11-gauge zinc-coated chain-link fabric and $1.6 \times 1.6-\mathrm{cm}$ hexagonalmesh poultry fencing, reinforced with $1.6 \times$ $257-\mathrm{cm}$ fencing tension bars and 7-gauge tension wire. Finished exclosures measured approximately $1.2 \times 2.2 \times 0.7 \mathrm{~m}$ (Fig. 1). We designed these exclosures to facilitate mass measurements by incorporating a chain-link mesh basket on the underside, in which the enclosed carcass could be suspended on a hanging scale. If necessary, antlers and lower legs were removed so that carcasses would fit within exclosures. Because lions routinely eviscerate prey shortly after killing (Hansen 1992), we mimicked this behavior by making a single 16-cm-deep midsagittal incision from sternum to pelvis and by puncturing lungs with a narrow incision through the rib cage.
We observed and measured carcasses at regular time intervals. We measured carcass mass prior to deployment, at deployment, and then, along with temperature, thereafter at 2-day intervals during early to mid-afternoon. We measured mass with a hanging spring scale $( \pm 0.23-\mathrm{kg}$ accuracy) after removing all possible dirt and debris. We measured external temperature of the elevated carcass with a handheld infrared sensor $\left( \pm 1{ }^{\circ} \mathrm{C}\right.$ accuracy $)$ at 13 predetermined points on exposed and down-facing carcass surfaces. We also recorded the downwind distance at which we first detected carcass odor prior to handling the carcass. We determined wind speed and direction with a handheld anemometer and measured distance of odor detection with a stretch- and temperature-resistant 30-m fiberglass tape. We monitored carcasses until tissue loss had stabilized (<1 kg loss per day) for 4-6 consecutive days.

We treated individual carcasses as sample units and so used carcass-specific summary statistics as our unit of analysis for statistical tests. We used a curve of time-specific tissue loss to interpolate time (in hours) to $25 \%, 50 \%$, 
and $75 \%$ wastage for each carcass. We calculated wastage rate relative to the difference between mass at deployment and mass at the end of active decomposition. For each carcass, we also calculated average daily maximum ambient temperature and average carcass temperature for the period between deployment and $75 \%$ wastage. We assumed that time to $75 \%$ wastage would be the period during which environmental conditions would have maximal effects on decomposition rates. Any less time, and we assumed that the effects of environmental conditions would likely not be fully realized; any more time, and we assumed that effects would likely be negligible.

We subsumed weather effects in a categorical variable that corresponded to the spring and early-summer drought (drought) and to the mid- to late-summer rainy period (monsoon). No rain fell prior to 13 July during the study (precipitation $=0.0 \pm 0.0\left[s_{\bar{x}}\right] \mathrm{cm}$, averaged over carcasses for the period [to $75 \%$ wastage] that each was monitored), and mean daily maximum temperature during this early part of our study period was $37.3 \pm 2.0{ }^{\circ} \mathrm{C}$ (again, averaged over carcass-specific monitoring periods). By contrast, after 13 July, mean total rainfall was $4.3 \pm 0.0 \mathrm{~cm}$, and mean daily maximum temperature was $31.9 \pm 0.08{ }^{\circ} \mathrm{C}$, averaged over carcasses. We concluded that this invariance of temperature and precipitation by "season" justified treating weather as a categorical rather than continuous effect. Treating weather as 2 seasons also accounted for other season-related weather factors that we did not measure, including cloud cover, which was greater during monsoon, and wind, which was greater during drought.

We used analysis of covariance and simple linear regression for statistical tests and to specify models (Sokal and Rohlf 1981). Treatment (cached versus exposed) and season (drought versus monsoon) were fixed effects, and initial carcass mass was a covariate (random effect), for models of time to $25 \%, 50 \%$, and $75 \%$ wastage. We specified additional models in which carcass temperature was the independent variable and times to $25 \%, 50 \%$, and $75 \%$ wastage were dependent variables; we also specified models in which treatment and season were independent variables, and distance to detection of carcass odor or difference between carcass temperature and ambient maximum temperature were the dependent variables. We used squared values of temperature and natural-log-transformed values of initial carcass mass $(\ln [x+1])$ in these models because inspection of scatter plots suggested that such transformations would yield betterperforming predictors corresponding to constant rather than variable rates of increase in wastage (Weisburg 1985). To stabilize variance, we transformed distance at which odor was first detected by natural logarithms (Weisburg 1985). We report only reduced models containing independent variables for which we rejected the hypothesis that parameters equaled 0 (at $\alpha=0.10)$. All of our statistical tests were explicitly related to a hypothesis and to elements of our experimental design, and so we did not control for type I experiment-wise errors (Sokal and Rohlf 1981).

\section{RESUlTS}

We deployed 9 carcasses between 14 June and 5 August 2007: 2 elk (Cervus elaphus), 2 mule deer (Odocoileus hemionus), 4 domestic cow calves, and 1 pronghorn (Antilocapra americana). Each species was deployed in pairs, with one carcass treated and the other untreated. The pronghorn was deployed as a singleton in the open (untreated). Initial masses averaged $69.2 \pm 16.9\left(s_{\bar{x}}\right) \mathrm{kg}$. Mean times to $25 \%, 50 \%$, and $75 \%$ wastage for all carcasses were $79.9 \pm 8.7,123.0 \pm 8.2$, and $157.4 \pm 10.0$ hours, respectively. Mean carcass surface temperatures (to $75 \%$ wastage) at midafternoon were $30.8 \pm 3.2^{\circ} \mathrm{C}$; mean maximum ambient temperatures at Wupatki NM were $34.3 \pm 1.0^{\circ} \mathrm{C}$.

Consistent with hypothesis 1 , times to $50 \%$ and $75 \%$ wastage (hours) were negatively related to carcass temperature (Ctemp ${ }^{2}$ ), although we did not reject the hypothesis that time to $25 \%$ wastage was unrelated to carcass temperature. Model statistics for time to $50 \%$ wastage were as follows: $r^{2}=0.671, F_{1,7}=$ $14.3, P=0.007$, root MSE $=15.1$, Ctemp $2 \beta$ $=-0.032$. Model statistics for time to $75 \%$ wastage were as follows: $r^{2}=0.429, F_{1,7}=5.3$, $P=0.056$, root $\mathrm{MSE}=24.2, \mathrm{Ctemp}^{2} \beta=$ -0.031 .

Initial carcass mass, treatment, and season had varying effects on wastage rate, difference between ambient maximum and carcass temperatures, and distance at which carcass odor was first detected (Table 1). We did not reject 
TABLE 1. Parameters for models relating carcass responses to the effects of initial mass and season (drought and monsoon) by treatment (cached and exposed) interaction, for 9 carcasses investigated near Flagstaff, Arizona, during summer 2007.

\begin{tabular}{|c|c|c|c|c|c|c|c|c|c|c|}
\hline \multirow{2}{*}{$\begin{array}{l}\text { Independent } \\
\text { variables and } \\
\text { model statistics }\end{array}$} & \multicolumn{2}{|c|}{$\begin{array}{l}\text { Time to } 25 \% \\
\text { wastage }(\mathrm{h})\end{array}$} & \multicolumn{2}{|c|}{$\begin{array}{l}\text { Time to } 50 \% \\
\text { wastage }(\mathrm{h})\end{array}$} & \multicolumn{2}{|c|}{$\begin{array}{c}\text { Time to } 75 \% \\
\text { wastage }(\mathrm{h})\end{array}$} & \multicolumn{2}{|c|}{$\begin{array}{c}\text { Air-carcass } \\
\text { temperature } \\
\text { difference }\left({ }^{\circ} \mathrm{C}\right)\end{array}$} & \multicolumn{2}{|c|}{$\begin{array}{l}\text { Distance to } \\
\text { detection of } \\
\text { carcass odor } \\
(\ln [\mathrm{m}+1])\end{array}$} \\
\hline & $\beta$ & $P$ & $\beta$ & $P$ & $\beta$ & $P$ & $\beta$ & $P$ & $\beta$ & $P$ \\
\hline Intercept & 202.2 & 0.003 & 234.5 & 0.002 & 165.3 & 0.000 & -3.3 & 0.223 & 2.75 & 0.000 \\
\hline $\begin{array}{l}\text { Initial carcass mass } \\
(\ln [\mathrm{kg}+1]) \\
\text { Season } \times \text { treatment }\end{array}$ & -30.1 & 0.031 & -27.9 & $\begin{array}{l}0.042 \\
0.024\end{array}$ & & 0.010 & & 0.015 & & 0.012 \\
\hline $\begin{array}{l}\text { Cached drought } \\
\text { Exposed drought } \\
\text { Cached monsoon } \\
\text { Exposed monsoon }\end{array}$ & & & $\begin{array}{r}30.5 \\
-23.4 \\
2.0 \\
0.0\end{array}$ & & $\begin{array}{r}25.5 \\
-52.2 \\
-8.4 \\
0.0\end{array}$ & & $\begin{array}{r}-5.3 \\
12.3 \\
-8.3 \\
0.0\end{array}$ & & $\begin{array}{r}0.54 \\
1.37 \\
-0.96 \\
0.00\end{array}$ & \\
\hline $\begin{array}{l}\text { Model } R^{2} \\
F \text { statistic (df) } \\
\text { Model } P \text { value } \\
\text { Root MSE }\end{array}$ & $\begin{array}{r}0.5 \\
7.2 \\
0.0 \\
19.7\end{array}$ & $\begin{array}{l}7 \\
1,7) \\
1\end{array}$ & $\begin{array}{r}0 . \\
12 . \\
0 . \\
9.6\end{array}$ & $\begin{array}{l}24 \\
(4,4) \\
17\end{array}$ & $\begin{array}{r}0.8 \\
12.2 \\
0.8 \\
13.2\end{array}$ & $\begin{array}{l}0 \\
3,5)\end{array}$ & $\begin{array}{r}0 . \\
10 . \\
0 . \\
4 .\end{array}$ & $\begin{array}{l}57 \\
(3,5) \\
15\end{array}$ & $\begin{array}{r}0 \\
10 \\
0 \\
0\end{array}$ & $\begin{array}{l}67 \\
(3,5) \\
12 \\
2\end{array}$ \\
\hline
\end{tabular}

the hypothesis that parameter coefficients equaled 0 for treatment by season relative to the time to $25 \%$ wastage or for initial carcass mass relative to the time to $75 \%$ wastage. Of relevance to hypothesis 2 , treatment (caching) increased times to $50 \%$ and $75 \%$ wastage during drought by an average 53.9 hours and 77.7 hours, respectively, but not during monsoon (Fig. 2a). Treatment did not have an effect on time to $25 \%$ wastage during either season. Consistent with hypothesis 3 , carcass surface temperature $\left({ }^{\circ} \mathrm{C}\right)$ was lower relative to ambient temperature for treated versus untreated carcasses by an average $17.6^{\circ} \mathrm{C}$ during drought and by an average $8.3{ }^{\circ} \mathrm{C}$ during monsoon (Fig. 2b). Consistent with hypothesis 4, odors of treated carcasses were detected at shorter distances compared to odors of untreated carcasses, by an average $37 \mathrm{~m}$ during drought and by an average $10 \mathrm{~m}$ during monsoon (Fig. 2c). Season had the greatest effect on odor detection, with average detection distance 31 $\mathrm{m}$ greater during drought compared to during monsoon.

\section{DisCUSSION}

Our sample size of 9 carcasses was small, which limited our ability to detect effects. Despite limited statistical power, we observed effects that were strong and consistent with prior hypotheses developed on the basis of ecological knowledge. Although this study does not support definitive conclusions about the effects of lion-like caching on carcasses, it does provide a basis for refining hypotheses, informing future studies of greater scope, and judiciously deepening our understanding of mountain lion behavior.

Our results are consistent with the notion that mountain lions are often in a race with microbes and arthropods to consume fleshy tissue from kills. During our study, arthropods, microbes, and desiccation removed $75 \%$ of consumable tissue from exposed carcasses within about 8 days, which is consistent with Braack's (1986) observations of impala (Aepyceros melampus) carcasses in Kruger National Park. Twenty-five percent of initial carcass mass was lost within roughly 3 days, with loss accelerating between days 3 and 6 . These wastage rates did not account for additional prospective losses caused by spoilage from toxins released by microbes (Janzen 1977), which are almost certainly detrimental to lions (Bauer et al. 2005). It seems more than happenstance that mountain lions in the vicinity of our study area typically spend between 2 and 3 days on a kill before moving on (Mattson et al. 2006), coincident with likely intensified competition with arthropods and microbes for remaining fleshy tissue.

From the presumed perspective of a feeding mountain lion, simulated caching had beneficial effects on both carcass wastage and temperature. The wastage effect was evident only during hotter, drier conditions of the spring and early-summer drought, but the 

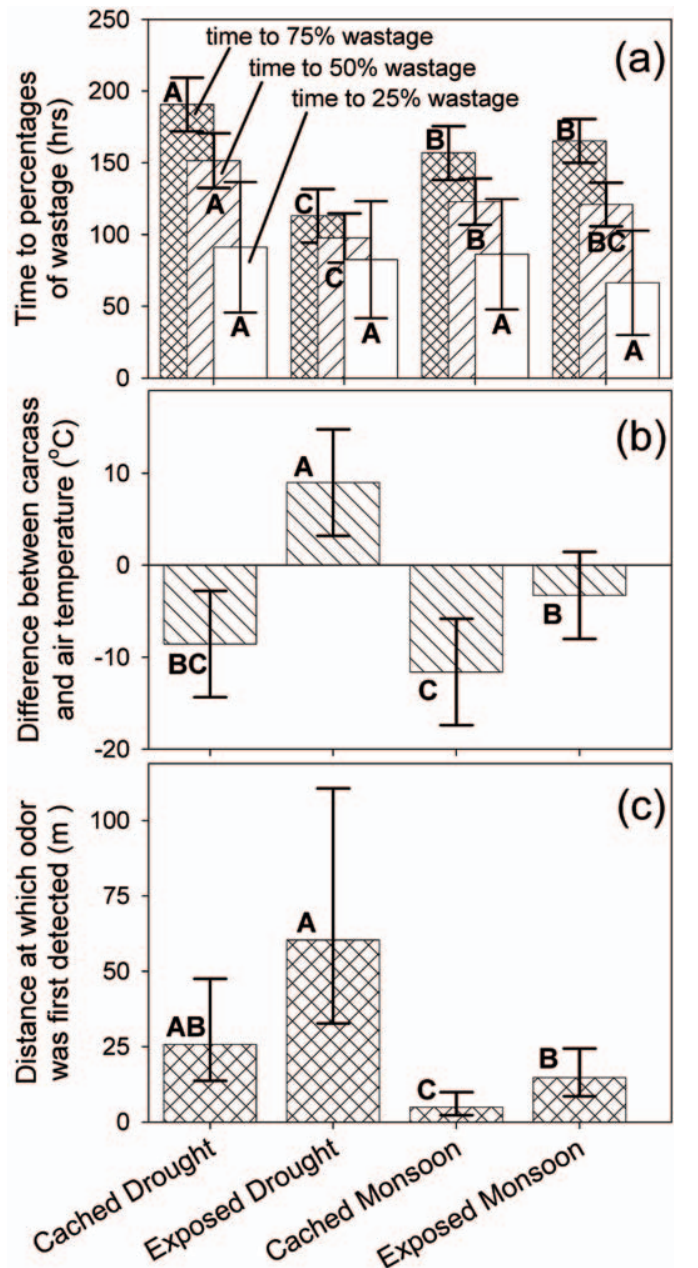

Fig. 2. Effects of season (drought and monsoon) and treatment (cached and exposed) on (a) time to percentages of wastage of carcass mass, (b) difference between carcass temperature and maximum daily air temperature, and (c) distance at which we first detected carcass odor downwind for 9 carcasses deployed during summer 2007 near Flagstaff, Arizona. Error bars represent 90\% confidence intervals. Values in the first panel (a) for time to 50\% wastage are least-squares means calculated to control for effects of initial carcass mass. Means denoted by bars with the same capital letters placed above them are from the same populations (based on multiple comparisons using $t$ tests and $\alpha=0.10$ ).

temperature effect was evident in some measure during both seasons of our study. During the drought, time to $50 \%$ wastage was prolonged by roughly 2.25 days, whereas time to $75 \%$ wastage was prolonged by roughly 3.25 days $-55 \%$ and $70 \%$ gains, respectively, over outcomes for exposed carcasses. These gains likely accrued, in part, through comparative reductions of carcass temperature, which would have reduced desiccation and negatively affected population sizes and activity levels of necrophilous arthropods (Payne 1965, Shean et al. 1993, Tantawi et al. 1996, Watson and Carlton 2005, Joy et al. 2006). We documented direct effects of carcass temperature on wastage but only after initial stages of decomposition, when desiccation was likely a major factor. These delayed effects of temperature are consistent with mediation primarily through the effects of arthropods, which presumably manifest most strongly during mid- to late stages of decomposition (Payne 1965, Joy et al. 2006).

We also documented substantial effects of weather and initial carcass mass on rates of mass loss. Large initial mass was associated with accelerated losses during the period of $50 \%$ wastage but more so during the initial period of $25 \%$ wastage, which was consistent with patterns observed by Hewadikarum and Goff (1991) for pigs of different masses. Assuming that caching is beneficial, this pattern suggests that mountain lions would have more to gain by shading and burying larger carcasses, all else equal. The substantially higher carcass temperatures and quicker wastages we observed during the drought also suggest that lions would benefit most from caching prey during hot, dry weather. On the other hand, lions may preserve little or no mass by caching prey during colder seasons or at higher elevations and latitudes. This hypothesis is consistent with the observed tendency for mountain lions in the vicinity of our study area to cache prey less often at higher elevations, all other factors equal (Mattson et al. 2006).

Caching appeared to reduce dissemination of odor, at least as detected by our crude olfactory senses, especially during the wetter monsoon season. This result is the most germane to potential interference competition by larger vertebrates, especially bears, wolves, and conspecifics (Murphy et al. 1998, Kunkel et al. 1999), and, moreover, suggests that although mass losses may not be affected by caching under cooler, moister conditions, odor dissemination may. Not unexpectedly, these results suggest that there may be several evolutionary explanations for caching behavior by mountain lions.

Our research raises a number of questions that provide direction for future investigations. What are the effects of caching on carcasses 
over a wider range of weather and climate conditions corresponding to different seasons, elevations, latitudes, and precipitation regimes? How might these different environments not only directly influence the effects of caching on carcass temperature and odor but also indirectly determine the benefits of caching with respect to area-wide populations of necrophilous arthropods (DeJong and Chadwick 1999, Gill 2005)? How does caching affect the proliferation of microbes and associated toxins, which may have major effects on carcass tissues (Janzen 1977, Shivik 2006)? What are the energetics of caching, especially related to carcass mass? What are the expenditures associated with carcass relocation, burial, and reburial? What are the energy gains from saved digestible tissue and the opportunity costs related to searching for and killing additional prey (e.g., Gendron and Reichman 1995)? How might caching behavior vary with intensity of competition for carcasses from other predators such as wolves and bears? Our research represents only the tip of the proverbial iceberg related to understanding caching behavior by mountain lions.

\section{ACKNOWLEDGMENTS}

Funding for this study was provided by the USGS Southwest Biological Science Center and by the Ecological Monitoring and Assessment Program at Northern Arizona University. We appreciate the assistance of Jan Hart, Terry Arundel, and Karan English with logistics and funding; the assistance of Sky Bischoff-Mattson and Susan Bischoff with data collection; the assistance of Richard Keller of the Arizona Game and Fish Department with locating carcasses; and the assistance of Charles Drost, Tad Theimer, and Jan Hart with manuscript reviews. Paulette Bierzychudek and Ken Clifton of Lewis and Clark College provided guidance for aspects of this project.

\section{Literature Cited}

Anderson, C.R., AND F.G. Lindzey. 2003. Estimating cougar predation rates from GPS location clusters. Journal of Wildlife Management 67:307-316.

Bauer, J.W., K.A. Logan, L.L. Sweanor, and W.M. BoYCE. 2005. Scavenging behavior in puma. Southwestern Naturalist 50:466-471.

Beier, P., D. Choate, And R. Barrett. 1995. Movement patterns of mountain lions during different behaviors. Journal of Mammalogy 76:1056-1070.
BRAACK, L.E.O. 1986. Arthropods associated with carcasses in northern Kruger National Park. South African Journal of Wildlife Research 16:91-98.

CatTs, E., AND M. GofF. 1992. Forensic entomology in criminal investigations. Annual Review of Entomology $37: 253-272$.

Červený, J., And H. Okarma. 2002. Caching prey in trees by Eurasian lynx. Acta Theriologica 47:505-508.

DEJong, G.D., AND J.W. ChaDWICK. 1999. Decomposition and arthropod succession on exposed rabbit carrion during summer and high altitudes in Colorado, USA. Journal of Medical Entomology 36: 833-845.

DeVault, T.L., O.E. Rhodes, JR., And J.A. Shivik. 2003. Scavenging by vertebrates: Behavioral, ecological, and evolutionary perspectives on an important energy transfer pathway in terrestrial systems. Oikos 102: $225-234$.

ElgmorK, K. 1982. Caching behavior of brown bears (Ursus arctos). Journal of Mammalogy 63:607-612.

Eltringham, S. 1979. The ecology and conservation of large African mammals. Macmillan Press, London. 286 pp.

Formanowicz, D.R., JR., P.J. Bradley, and E.D. Brodie, JR. 1989. Food hoarding by the least shrew (Cryptotis parva): intersexual and prey type effects. American Midland Naturalist 122:26-33.

Gendron, R., And O. Reichman. 1995. Food perishability and inventory management: a comparison of three caching strategies. American Naturalist 145:948-968.

GiLL, G. 2005. Decomposition and arthropod succession on above ground pig carrion in rural Manitoba. Canadian Police Research Center Technical Report TR-06-2005, Ottowa, Canada.

Goff, M.L. 1992. Problems in estimation of postmortem interval resulting from wrapping of a corpse: a case study from Hawaii. Journal of Agricultural Entomology 9:237-243.

Hansen, K. 1992. Cougar: the American lion. Northland Publishing, Flagstaff, AZ. 129 pp.

HewadiKaRAM, K.A., AND M.L. GofF. 1991. Effect of carcass size on rate of decomposition and arthropod succession patterns. American Journal of Forensic Medicine and Pathology 12:235-240.

Hornocker, M.G. 1970. An analysis of mountain lion predation upon mule deer and elk in the Idaho Primitive Area. Wildlife Monograph 21:1-39.

Isiche, J., J.E. Hillerton, AND F. Nowell. 1992. Colonization of the mouse cadaver by flies in southern England. Medical and Veterinary Entomology 6: 168-170.

JANZEN, D.H. 1977. Why fruits rot, seeds mold, and meat spoils. American Naturalist 111:691-713.

Joy, J.E., N.L. Liette, and H.L. Harrah. 2006. Carrion fly (Diptera: Callpiphoridae) larval colonization of sunlit and shaded pig carcasses in West Virginia, USA. Forensic Science International 164:183-192.

Kớćrek, P. 2003. Decomposition and Coleoptera succession on exposed carrion of small mammal in Opava, the Czech Republic. European Journal of Soil Biology 39:31-45.

KRUUK, H. 1972. The spotted hyena: a study of predation and social behavior. University of Chicago Press, Chicago, IL. 335 pp.

Kunkel, K., T. Ruth, D. Pletscher, and M. Hornocker. 1999. Winter prey selection by wolves and cougars in and near Glacier National Park, Montana. Journal of Wildlife Management 63:901-910. 
Macdonald, D. 1976. Food caching by red foxes and some other carnivores. Zeitschrift für Tierpsychologie 42: 170-185.

Mann, R., W. Bass, and L. Meadows. 1990. Time since death and decomposition of the human body: variables and observations in case and experimental field studies. Journal of Forensic Science 35:103-111.

Martin, I.G. 1984. Factors affecting food hoarding in the short-tailed shrew Blarina brevicauda. Mammalia 48:65-71.

Martinez, E., P. DuQue, and M. WolfF. 2007. Succession pattern of carrion-feeding insects in Paramo, Columbia. Forensic Science International 166:182-189.

Mattson, D., J. Hart, M. Miller, and D. Miller. 2006. Predation and other behaviors of mountain lions in the Flagstaff Uplands. Pages 31-42 in D. Mattson, editor, Mountain lions of the Flagstaff Uplands. USGS Open-File Report 2007-1062. Available from: http://pubs.usgs.gov/of/2007/1062/of2007-1062.pdf

MECH, L.D., AND L.G. ADAms. 1999. Killing of a muskox, Ovibos moschatus, by two wolves, Canis lupus, and subsequent caching. Canadian Field-Naturalist 113: 673-675.

Michener, G.R. 2000. Caching of Richardson's ground squirrels by North American badgers. Journal of Mammalogy 81:1106-1117.

Murphy, K.M., G.S. Felzien, M.G. Hornocker, and T.K. RUTH. 1998. Encounter competition between bears and cougars: some ecological implications. Ursus 10:55-60.

Muths, E. 1998. An observation on caching of prey by a long-tailed weasel (Mustela frenata). Southwestern Naturalist 43:106.

PaYne, J.A. 1965. A summer carrion study on the baby pig Sus scrofa L. Ecology 46:592-602.

Ruth, T.K. 2004. Ghost of the Rockies: the Yellowstone cougar project. Yellowstone Science 12:13-24.

Samelius, G., R.T. Alisauskas, and S. Larivière. 2007. Survival rate of experimental food caches: implications for arctic foxes. Canadian Journal of Zoology 85:397-403.

Samelius, G., R.T. Alisauskas, S. Larivière, C. Bergman, C.J. Hendrickson, K.L. Phipps, And C. WoOd. 2002.
Foraging behaviours of wolverines at a large Arctic Goose colony. Arctic 55:148-150.

Shean, B.S., L. Messinger, and M. Papworth. 1993. Observations of differential decomposition on sun exposed v. shaded pig carrion in coastal Washington State. Journal of Forensic Sciences 38:938-949.

SHIVIK, J.A. 2006. Are vultures birds, and do snakes have venom, because of macro- and microscavenger conflict? BioScience 56:819-823.

SKLEPKOVYCH, B.O., AND W.A. Montevecchi. 1996. Food availability and food hoarding behaviour by red and arctic foxes. Arctic 49:228-234.

Smith, C.C., AND O.J. Reichman. 1984. The evolution of food caching by birds and mammals. Annual Review of Ecology and Systematics 15:329-351.

SOKAL, R.R., AND F.J. ROHLF. 1981. Biometry: the principles and practices of statistics in biological research. 2nd edition. W.H. Freeman, New York. 859 pp.

Tantawi, T.I., E.M. El-Kady, B. Greenberg, and H.A. EL GHAFFAR. 1996. Arthropod succession on exposed rabbit carrion in Alexandria, Egypt. Journal of Medical Entomology 33:566-580.

Tessmer, J.W., and C.L. Meek. 1996. Dispersal and distribution of Calliphoridae (Diptera) immatures from animal carcasses in southern Louisiana. Journal of Medical Entomology 33:566-580.

Turner, B., AND P. Wiltshire. 1999. Experimental validation of forensic evidence: a study of the decomposition of buried pigs in a heavy clay soil. Forensic Science International 101:113-122.

VANDER WALL, S.B. 1990. Food hoarding in animals. University of Chicago Press, Chicago, IL. 453 pp.

Watson, E.J., and C.E. Carlton. 2003. Spring succession of necrophilous insects on wildlife carcasses in Louisiana. Journal of Medical Entomology 40:338-347.

2005. Insect succession and decomposition of wildlife carcasses during fall and winter in Louisiana. Journal of Medical Entomology 42:193-203.

Weisburg, S. 1985. Applied linear regression. 2nd edition. John Wiley \& Sons, New York. 324 pp.

Received 12 October 2008 Accepted 29 May 2009 